DOI: https://doi.org/10.32839/2304-5809/2021-3-91-50

UDC 81'25

Khar Mariia, Hrytsiv Nataliia

Lviv Polytechnic National University

\title{
ANALYSIS OF MARKETING SLOGANS FROM THE PERSPECTIVE OF TRANSLATION STUDIES
}

Summary. This research is focused on a detailed analysis of advertising slo-gans of well-known food brands, linguistic features of slogans, translation strategies, linguistic shifts applied and difficulties translators face in the process of translating. The relevance of the topic is determined by the need to determine the features of the translation of advertising slogans, the influence of cultural factors on the translation of advertising slogans, the influence of verbal and nonverbal components of advertising on its perception by the target audience. For the study, 50 advertising slogans of various food companies were carried out. Features and strategies of translation of advertising slogans, lexical-grammatical, stylistic and other transformations applied to the target text are established. According to Catford's classification, the main dominant category of linguistic transformations is the transformation of sentence structure, which is used in the translation of approximately $38 \%$ of advertising slogans. Changes in rank and changes within the language system of the target language are $23 \%$ and $27 \%$, respectively, and changes in grammatical classes of words - $12 \%$. This work has theoretical value in terms of studying unique features of the discourse of advertising and peculiarities of translation of advertising slogans, and practical value for use of verbal and nonverbal elements of advertising as a means of influencing consumers. Keywords: advertising translation, marketing slogan, linguistic analysis, lin-guistic shift, translation strategy, source language (SL), source text (ST), target lan-guage (TL), target text (TT).

Хар М.Є., Гриців Н.М.

Національний університет «Львівська політехніка»

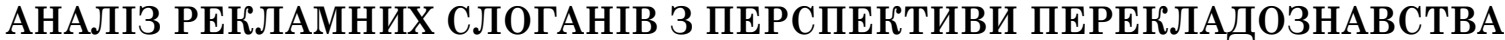

Анотація. У сучасному суспільстві одним із найпотужніших засобів впливу на людей є реклама. Ця галузь дуже інтенсивно розвивається протягом останніх десятиліть та доволі часто стає темою дискусій серед науковців, зок-рема лінгвістів. одним з найважливіших елементів комунікації між брендами та споживачами продукції є рекламне гасло. Слоган передає основну ідею рекламної кампанії. У статті детально проаналізовано рекламні слогани відомих харчових компаній, особливості та стратегії їх перекладу, лінгвістичні зсуви та трансформації, труднощі, з якими стикаються перекладачі у процесі роботи. Актуальність теми визначається необхідністю визначення особливостей перекладу рекламних слоганів, впливу культурних чинників на переклад рекламних гасел, впливу вербальних та невербальних компонентів реклами на її сприйняття цільовою аудиторією. Для проведення дослідження було здійснено вибірку рекламних слоганів різних харчових компаній. Встановлено особливості та стратегії перекладу рекламних гасел, а також зсуви, застосовані до цільового тексту при перекладі. За класифікацією лінгвістичних зсувів Дж. Кетфорда основною домінантною категорією лінгвістичних трансформацій встановлено зсуви структури речень, які застосовуються в перекладі приблизно 38\% рекламних слоганів. Зміни рангу та внутрішньосистемні зміни в межах цільової мови складають відповідно $23 \%$ та $27 \%$, а класові зсуви - лише $12 \%$. Слогани проаналізовано за типом використаної стратегії перекладу відповідно до класифікації Честермана. Виявлено приклади синтаксичних, граматичних та семантичних трансформацій лінгвістичних одиниць при перекладі з мови-джерела на мову-ціль. Розглянуто випадки доместикації рекламних гасел відповідно до норм цільової мови, у процесі перекладу яких використано прагматичну стратегію перекладу. Робота має теоретичну цінність з точки зору вивчення унікальних рис дискурсу реклами та особливостей перекладу рекламних гасел, та практичну цінність для застосування вербальних та невербальних елементів реклами як засобів впливу на споживача. Рекламний дискурс $є$ цікавою сферою для подальших досліджень.

Ключові слова: переклад реклами, рекламне гасло, слоган, лінгвістичний аналіз, лінгвістичний зсув, лінгвістична трансформація, стратегія перекладу, мова-джерело, мова-ціль.

Droblem statement. Due to the processes of globalization, which had led to active cooperation between countries, especially in the field of trade, a significant number of companies and corporations entered new markets. For this reason, it be-came necessary to translate advertising slogans taking into account the peculiarities of a source text and its impact on potential rescipient.

In modern society, advertising is one of the main tools that influence people's choices when buying goods and services. Therefore, studying the mechanisms of verbal influence of advertising texts and analysing language means used are crucial for correct translation of the message into different markets, overcoming cultural barriers and preserving brand values.

The latest research and published works analysis. Analysis of advertising translation shows that the first scientific works in the field appeared in the 1970s when Canadian linguist Tatilon began investigation of the nature of advertising translation and claimed that translation process involves more than mere interlingual transfer from a written text into a SL to another in TL [9, p. 1].

Other linguists who explored the problems of advertising discourse are Christina Valdes, Raquel de Pedro, Karen Smith and Adab Beverly. In particular, researchers pay special attention 
to the localization of advertising discourse in the translation of Internet advertising, verbal and nonverbal components of advertising, analyse advertising translation from pragmatic, semiotic and other sides. Moreover, they emphasize the role of culture in translation, the way the audience interprets message through which equivalence is achieved and how the stylistics of the original messages is preserved in the main text.

Identification of previously unsettled parts of the general problem. An advertising slogan is a brief, apt and memorable phrase or sentence that clearly emphasizes the advantages of a particular product or service, distinguishing it from competitors. Translation strategies and shifts applied in the process of translating slo-gans from English into Ukrainian and vice versa are to be considered in this article. Other remaining issues are revealing characteristic features of slogans and their trans-lation equivalents, peculiarities of translation of advertising slogans, difficulties faced by translators and changes made to domesticate or foreignize the text.

The main purposes of this research article are:

- to reveal the main peculiarities of advertising translation;

- to analyze marketing slogans, indicating their linguistic features;

- to define ideas conveyed through the use of certain linguistic units ;

- to analyze the influence of verbal expressions on feelings and emotions of potential consumers;

- to determine translation strategies and shifts applied in the process of translating slogans;

- to reveal modifications made to domesticate and improve the target text.

The main part. Translating slogans is a difficult process that requires good knowledge of both source and target language and culture, having skills in the area of translation and abilities to transfer the message from SL to TL so that it has the same impact on target audience. It aims to create text that will make a person buy a product, use service or keep in mind the brand.

For instance, chocolate bar Snickers slogans sound "You're not you when you're hungry", "Hungry? Why wait?", "Hungry? Grab a Snickers" (SL).The company uses declarative, interrogative and imperative sentences in order to attract public attention and to offer its product. Localized Ukrainian translation is a bit different: “Ти - не ти, коли голодний. Не гальлуй! Снікерсуй" (TL). The verb "снікерсувати" is a neologism created according to the rules of Ukrainian word-building system. This is an example of domestication of advertising text used to make slogans sound more natural and be closer to the local consumer. The translator tries to evoke the same feelings and emotions that are reproduced in the source text and applies shifts to create required reception in the target language environment. The following example shows structural shift: source text "Grab a Snickers" is Predicate + Object and translated into the predicate "Снікерсуй" in target text. This example also illustrates unit shift: ST in the form of phrase (English) is translated into TT in the form of word (Ukrainian). Moreover, we may claim that Nida's notion of dynamic equivalence, where 'the focus of attention is directed, not so much toward the source message, as toward the receptor response' is applied [1, p. 270]. "Не гальлуй" may be defined as antonymic translation of "Hungry? Why wait?" that is identified by Rezker as "the substitution of the SL word by a TL word with opposite meaning."

So, the main idea of this advertising campaign is to appeal to a young audience that enjoy hip-hop and use chocolate bar Snickers as a kind of selfexpression, freshness, and for raising a social status.

First of all, comparing Ukrainian and English versions of brand slogans, we see that there are structural differences between original texts and their translation equivalents. To illustrate this, we are going to examine advertising slogans of Bounty chocolate bar manufactured by Mars.

English source language text "Taste of paradise" is translated into Ukrainian as "Райська насолода." It is localized according to the linguistic and cultural peculiarities of the local market. The noun paradise converts into an adjective paŭcbкa and changes the word order, preceding the noun насолода. So, translators adapt text using linguistic units of different parts of speech. According to the classification of shifts within the framework of a linguistic theory of translation by Scottish linguist Catford, the above change of class is denoted by the term "class shift."

These slogans are samples of covert translation, namely "translation which enjoys the status of an original source text in the target culture" [7, p. 93].

Second important feature is that marketing expressions often use imperative mood of verbs, name of the trademark or a hint at the direct purpose of the product in the text of the message. Notable examples are Orbit slogans "Eat. Drink. Chew" and “Їю, nuй, жуй Opбim" (original slogan and its translation into Ukrainian), in which Ukrainian equivalent simultaneously combines all three aspects. Moreover, they indicate the sequence of actions for product that must be done, as well as Oreo's one that sounds 'Twist, Lick, and Dunk" or “Покрути, лизни, булькни в молоко” (Oreo, English ST and Ukrainian TT). Peculiarities of translating of these expressions into Ukrainian are that in both cases imperative mood is used and the last verb is not just translated but also reinforced by additional component that is either direct object or adverbial modifier of place. The Orbit's motto emphasizes that chewing gum is consumed after eating and drinking whereas slogan of company Oreo represents a special ritual or way how to eat cookies that is in the interest of children.

Thirdly, the uniqueness and values of the advertised object or its other characteristics are often emphasized.

Advertising campaign of Aero chocolate actively uses the effect of bubbles, which are even part of the fonts and inscriptions. Bubbles are seen as tiny air pockets that differentiate Aero from the competitor's chocolate bars and show uniqueness of the product. Entering the mouth they melt on the tongue. These characteristics are represented even through linguistic expressions.

Vivid Aero slogan "Feel the bubbles" as well as its TL equivalent "Відиуй $\boldsymbol{я ⿻}$ тануть бульбашки” stimulates people to enjoy a product 
and new experience. Comparing them it should be pointed out that Ukrainian translation is changed by addition of verb "танути". New element is introduced to emphasize and properly convey the impression that product creates. So, the consumers may better understand that the motto tries to associate your feelings when eating Aero with its taste and melting of bubbles. Differences in structure and unit shifts are used intentionally to make text closer to target audience.

Furthermore, imagery and impressiveness are used to influence the recipients of text. They may be created by semantic properties of words.

The company "Lasunka" that is the leading producer of ice-cream in Ukraine in its marketing and advertising company uses slogan "Ласунка виробник иастя" (SL text). Products are released into the European market under the motto "Lasunka is the producer of happiness". Manufacturer uses a vivid metaphor to make consumers associate ice-cream with the abstract feeling of happiness, so the text combined with the image expresses feelings of joy, happiness and love that are the main values of this family brand.

We may also pay attention to the name of the company. Noun ласунка is defined in Worldwide Dictionary of Ukrainian Language as "та, що любить ласощі" and underlines delicious taste of ice-cream.

Another Ukrainian company named Sandora uses such slogans "Краший сік, народжений сонцел!" (SL) or “The best juice, born by the sun!" (TL) in its advertising campaign. Intra-system shift occurs during the translation process when Ukrainian word “кращий", which is the comparative degree of adjective "добрий", is translated into English in the superlative degree "best". Moreover, the metaphor "народжений сонцем" is literally translated into target language without any alterations in meaning. For this reason, mentioned above utterances are fully equivalent. They not only have the same form and content but also "trigger the same impact on the TL audience as the original wording did upon the SL audience" [5].

Juice, made from fruits that are full of energy of the sun, is associated with bright colours, unforgettable impressions and special spirit. Yellow and orange shades are used to show that your morning is always good and happy when you start your day with juice Sandora.

In addition, the message often evokes positive emotions and pleasant associations. Good examples are M\&M's mottos: "The milk chocolate melts in your mouth, not in your hand" (ST), “Тане в pomi, а не в руках"(TT). Concerning their linguistic characteristics, Ukrainian translation is highly simplified and much shorter than English one. Omission of pronouns your and noun phrase the milk chocolate simultaneously with addition of adversative coordinating conjunction " $a$ " created brief and clear structure of slogan that is less expressive than English utterance. Moreover, intrasystem shift occurs when SL singular noun "hand" turns into a TL plural "руки."

Next, English slogans in interrogative form are transformed into Ukrainian imperative sentences. "Twix, Need a Moment?" and its translation used in the Ukrainian market "Зроби nayзy - з'їю Twix" are examples of marketing slogans of chocolate bar Twix made by Mars. The Ukrainian way of translating motto applies reconstruction of source text, rebuilding question into imperative mood and addition of the verb «їсти» aimed to create brief and catchy pattern with the same sense. The company drops a hint that a moment with Twix is worthy of your attention and time.

Other techniques applied in the translation process are alliteration and assonance. The sound of letters stresses some words and sets the mood of statement. Here "moment" is associated with very short period of time that brings positive changes.

Finally, many slogans contain an allusion to new opportunities, changes, and discoveries that are possible with their products.

The famous brand of coffee Nescafe offers to start the day with a cup of their drink: "It all starts with a Nescafe" (SL text), "Bce noчuнаembcя 3 $\boldsymbol{N E S C A F E " ~ ( T L ~ t e x t ) . ~ L i t e r a l ~ t r a n s l a t i o n ~ a l l o w s ~}$ transmitting the necessary sense and mood of the utterance without any other changes except omission of pronoun it.

The main idea behind the slogan is not just traditional sense of coffee, but also Nescafe as a tool for achieving new amazing possibilities in other areas of life.

Advertising campaign of the company is based on family values, friendship and other wonderful moments present in everyone's life. Special taste and aroma of coffee play a particular role in evoking thoughts and emotions that stem from previous experiences and memories, so everyone will definitely want to enjoy this special beverage.

Strategies of translating advertising slogans. According to the Chesterman's classification of translation strategies our slogans are translated using translation strategies where target text is produced through manipulation with linguistic material. He claims that "if syntactic strategies manipulate the form, and semantic strategies manipulate meaning, pragmatic strategies can be said to manipulate the message itself'. Analyzing our data we obtained the following results:

1. Syntactic/grammatical strategies. A large proportion of slogans is translated literally, some of them apply unit and level shifts, or change the structure of phrases, clauses or sentences. They have the same form, content and impact on consumers. For example, "Солодкий знак якості" - "sweet quality mark", "Кращий сік, народжений сонцем!" "The best juice, born by the sun!", "Producer of happiness" - "Ласунка - виробник щастя".

2. Semantic strategies. Sometimes it is necessary to use synonyms, antonyms, paraphrasing and trope changes in order to domesticate and improve the text. For instance, "Made with laughter"- "Поділися посмішкою", "Taste the rainbow" - "Спробуй веселку", "Taste of paradise" - "Райська насолода", "Good Food, Good Life" - "Якість продуктів, якість життя".

3. Pragmatic strategies. It is important to pay attention to differences in the perception of the same text by audience of different cultures. Differences in initial knowledge, beliefs, values and behavioural norms must be taken into account. For example, "Hungry? Grab a Snickers" "Не гальмуй! Снікерсуй”, "Twix, Need a Moment?" 
Frequency of the Category Shift Occurrence

Table 1

\begin{tabular}{|c|c|c|c|c|c|c|c|}
\hline \multirow[b]{2}{*}{ № } & \multirow[b]{2}{*}{ Company } & \multicolumn{2}{|c|}{ Advertising slogans of the company } & \multicolumn{4}{|c|}{ Types of category shifts } \\
\hline & & source language & target language & $\begin{array}{l}\text { structure- } \\
\text { shifts }\end{array}$ & $\begin{array}{l}\text { class- } \\
\text { shifts }\end{array}$ & $\begin{array}{l}\text { unit- } \\
\text { shifts }\end{array}$ & $\begin{array}{l}\text { intra- } \\
\text { system } \\
\text { shifts }\end{array}$ \\
\hline 1 & Snickers & $\begin{array}{l}\text { "You're not you when } \\
\text { you're hun-gry. Hungry? } \\
\text { Grab a Snickers" }\end{array}$ & $\begin{array}{c}\text { “Ти - не ти, коли } \\
\text { голодний. Не гальмуй! } \\
\text { Снікерсуй” }\end{array}$ & + & + & + & + \\
\hline 2 & Bounty & "Taste of paradise" & "Райська насолода" & + & + & - & - \\
\hline 3 & Roshen & “Солодкий знак якості” & "Sweet quality mark" & + & - & - & - \\
\hline 4 & Sandora & $\begin{array}{c}\text { “Кращий сік, } \\
\text { народжений сонцем!" }\end{array}$ & $\begin{array}{l}\text { "The best juice, } \\
\text { born by the sun!" }\end{array}$ & - & - & - & + \\
\hline 5 & Lasunka & $\begin{array}{c}\text { “Ласунка - виробник } \\
\text { щастя" }\end{array}$ & "Producer of happi-ness" & - & - & - & - \\
\hline 6 & $\begin{array}{c}\text { The Laughing } \\
\text { cow }\end{array}$ & "Made with laughter" & “Поділися посмішкою” & + & - & - & + \\
\hline 7 & Skittles & "Taste the rainbow" & “Спробуй веселку” & - & - & - & - \\
\hline 8 & Kit Kat & $\begin{array}{c}\text { "Have a break. Have } \\
\text { a Kit-Kat" }\end{array}$ & "С пауза, є Kit-Kat" & - & - & - & + \\
\hline 9 & Twix & "Twix, Need a Moment?" & “Зроби паузу - з'їж Twix” & + & - & + & + \\
\hline 10 & Nestle & "Good Food, Good Life" & $\begin{array}{l}\text { "Якість продуктів, } \\
\text { якість життя" }\end{array}$ & + & + & - & + \\
\hline 11 & Aero & "Feel the bubbles" & $\begin{array}{c}\text { "Відчуй як тануть } \\
\text { бульбашки” }\end{array}$ & + & - & + & - \\
\hline 12 & Nescafe & $\begin{array}{c}\text { "It all starts } \\
\text { with a Nescafe" }\end{array}$ & $\begin{array}{c}\text { "Bсе починається } \\
\text { 3 NESCAFE" }\end{array}$ & - & - & - & - \\
\hline 13 & M\&M's & $\begin{array}{l}\text { "The milk chocolate } \\
\text { melts in your mouth, } \\
\text { not in your hand" }\end{array}$ & $\begin{array}{l}\text { "Тане в роті, } \\
\text { а не в руках" }\end{array}$ & + & - & + & + \\
\hline 14 & Orbit & "Eat. Drink. Chew" & “Їж, пий, жуй Орбіт" & + & - & + & - \\
\hline 15 & Oreo & "Twist, Lick, and Dunk" & $\begin{array}{l}\text { "Покрути, лизни, } \\
\text { булькни в молоко" }\end{array}$ & + & - & + & - \\
\hline
\end{tabular}

Source: developed by the authors

and "Зроби паузу - з'їж Twix", "Feel the bubbles""Відчуй як тануть бульбашки", "Twist, Lick, and Dunk" - "Покрути, лизни, булькни в молоко".

The next step of our study is to analyze advertising slogans according to Catford's classification of linguistic shifts.

It is found from the Table 1 above that the dominant category shifts are structure shifts (38\%). The next are intra-system shifts with the percentage of $27 \%$ and unit shifts that amount to approximately $23 \%$. The last are class shifts which make up somewhere in the region of $12 \%$ of linguistic shifts applied in the process of translating slogans.

Moreover, $12 \%$ of our pairs of translated text have no shifts applied. They are full equivalents of the original slogans.

In addition, $35 \%$ of source text is translated applying simultaneously at least two kinds of category shifts.

Conclusions. Advertising text is one of the most popular subjects of study in modern linguistics. Becoming an integral part of public life, today advertising is de-fined as a part of culture that develops according to its own laws and is characterized not only by unlimited possibilities of influence, but also by specific forms of expres-sion.

Advertising slogans are short and precise. For this reason, translating of slo-gans is a process that requires not only experience in the sphere of translation, but also perfect skills, good knowledge of source and target language and culture. Very often translators face difficulties trying to convey the main idea, expressed in the source text, when translating the message literally. It is sometimes necessary to modi-fy the message in order to domesticate and improve the target text, or, in other words, to apply linguistic shifts. They make text sound more natural to local market.

Having analyzed our data according to Catford's classification of linguistic shifts, we revealed that the dominant category shifts are structure-shifts. They are applied to $38 \%$ of source text. Intrasystem shifts $(27 \%)$ and unit shifts $(23 \%)$ are no less important and occur in combination with other types of shifts. The last type are class shifts which make up somewhere in the region of $12 \%$. Some

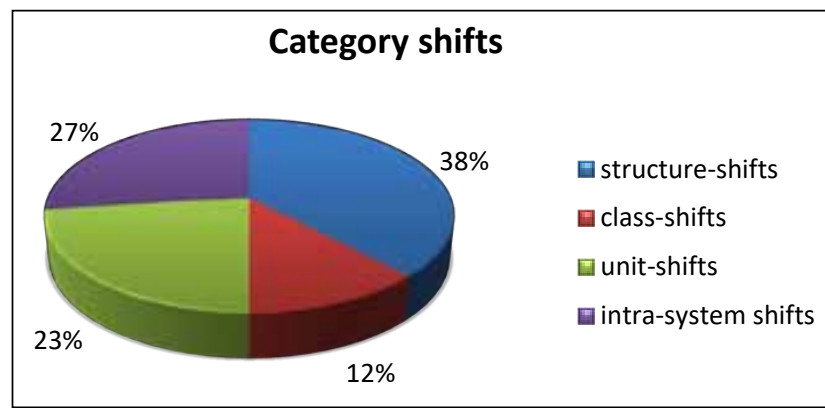

Figure 1. Results of advertising slogans analysis according to Catford's classification

Source: developed by the authors 
pairs of analysed data are full equivalents of the original slogans and have no shifts applied.

In an advertising campaign image, text and sound reproduce a single advertis-ing concept. Thus, the verbal components appear in combination with other elements which intensify text, make associations, form a specific picture and evoke feelings and emotions. They emphasize benefits of promoted brand, its uniqueness, represent product in a way that brings excitement, fun and unforgettable impressions. Vivid metaphors, fresh, creative and easy to remember expressions make brands attractive and special.

Moreover, common features of slogans and their translation equivalents were identified. The following results were received: slogans comprise frequent use of imperatives, establish focus on the desired effect on the target audience, emphasize uniqueness and values of the advertised object and use imagery and impressiveness to influence the recipients of text.

To sum up, slogan is concise, aphoristic and memorable motto, aimed to con-vey the basic idea of the advertising campaign. In the process of translating advertis-ing it is important to preserve the communicative effect of the source text, solve both purely linguistic problems and ones of sociolinguistic adaptation of the text. Therefore, fast changing discourse of advertising is an interesting area for further research.

\section{References:}

1. Baker Mona, Saldanha Gabriela (editors) (2011) Routledge encyclopedia of translation studies. 2nd ed. London \& New York: Routledge.

2. Deta Maria Sri Darta Levỳ's (2015) Minimax Strategy in Translating a Popular Article: Theory in Practice. Phenomena, vol. 15 , no. 1 , pp. $75-80$.

3. Gil Bardaji Anna (2009) Procedures, techniques, strategies: translation process operators. Perspectives, Studies in Translation Theory and Practice, vol. 17, no. 3, pp. 161-173. Available at: https://www.tandfonline.com/doi/ full/10.1080/09076760903249372?src=recsys (accessed 10 March 2021).

4. Gumenchuk Olga (2020) Peculiarities of translation of advertising and news-paper-informative texts. Leonid Yuzkov Khmelnytsky University of Management and Law, Khmelnytsky. Available at: http://englishcontext.kpnu.edu.ua/2020/03/18/peculiarities-of-translation-of-advertising-and-newspaperinformative-texts/

5. Leonardi Vanessa (2000) Equivalence in Translation: Between Myth and Reality. Translation Journal, vol. 4, no. 4. Available at: https://translationjournal.net/journal/14equiv.htm

6. Mars, Incorporated. Available at: https://www.mars.com/

7. Munday Jeremy (2008) Introducing Translation Studies: Theories and Applications. 2nd ed. Routledge, London, New York, pp. 89-97.

8. Nestle. Available at: https://www.nestle.com.mt/

9. Valdes Christina (2011) Advertising translation, Handbook of Translation Studies edited by Yves Gambier, Luc van Doorslaer, vol. 2. John Benjamins Publishing, pp. 1-5.

10. Valdes Cristina (2019) Advertising translation and pragmatics. The Routledge Handbook of Translation and Pragmatics. University of Oviedo: Routledge, pp. 171-190. Available at: re-searchgate.net/publication/336680607_ Advertising_translation_and_pragmatics 